\title{
Strategi Penguatan Potensi Desa dengan Karakteristik Degradasi Lahan di Desa Panggung Duwet, Kabupaten Blitar
}

\section{(Strategy for Strengthening Village Potential with Characteristics of Land Degradation in Panggung Duwet Village, Blitar District)}

\author{
Wahyu Santoso ${ }^{1}$, Rossyda Priyadharshini ${ }^{2}$, Maroeto ${ }^{2}$ \\ 1 Program Studi Agribisnis, Fakultas Pertanian, UPN "Veteran" Jawa Timur, Jl. Rungkut Madya, Gunung Anyar, \\ Kecamatan Gunung Anyar, Kota SBY, Jawa Timur 60294. \\ 2 Program Studi Agroteknologi, Fakultas Pertanian, UPN ”Veteran” Jawa Timur, Jl. Rungkut Madya, Gunung Anyar, \\ Kecamatan Gunung Anyar, Kota SBY, Jawa Timur 60294 \\ *Penulis Korespondensi: wahyu.agri@upnjatim.ac.id \\ Diterima Oktober 2018/Disetujui Maret 2020
}

\begin{abstract}
ABSTRAK
Tujuan program Kuliah Kerja Nyata (KKN) Bela Negara Desa Prioritas Nasional adalah: 1) Mensinergikan kearifan lokal sosial budaya dengan karakteristik perekonomian masyarakat untuk pencegahan degradasi lahan pertanian melalui program KKN, dan 2) Merumuskan strategi untuk meningkatkan potensi desa menuju desa maju dan mandiri. Metode pengumpulan data dilakukan dengan dua cara, yaitu data primer diperoleh dengan cara survei, kuesioner, dan wawancara; data sekunder berupa data yang terdokumentasi secara baik seperti Kabupaten Blitar dalam angka, Kecamatan Kademangan dalam angka, maupun laporan penyelenggaraan pemerintahan desa atau laporan pertanggungjawaban Desa Panggung Duwet Tahun 2018. Metode analisis data dilakukan dengan pendekatan metode intervensi sosial dan analisis SWOT. Hasil pelaksanaan program KKN Bela Negara Desa Prioritas Nasional di Desa Panggungduwet, Kecamatan Kademangan diimplementasikan kedalam progam kerja, yaitu penghijauan, pengolahan limbah menjadi pupuk organik dan kerajinan, pengolahan pangan komoditas unggulan seperti sirup rambut jagung, donat singkong, dan keripik singkong. Analisis situasi desa memperlihatkan masih terdapat kelemahan, yaitu kurangnya kesediaan air, terutama di musim kemarau untuk pertanian sejalan dengan peluang yang ada, yaitu mengupayakan pupuk organik dengan memanfaatkan limbah dan kerajinan limbah gergaji kayu dijual sehingga potensi tersebut diharapkan menjadi katalisator perkembangan desa menjadi maju dan mandiri. Keberadaan KKN Bela Negara Desa Prioritas Nasional dapat meninggalkan kesan baik sehingga masyarakat bersedia mulai merubah perilaku buruk pengelolaan lahan pertanian yang mengabaikan kaidah konservasi dan bertambahnya pengetahuan dan keterampilan olahan limbah maupun olahan pangan guna meningkatkan kesejahteran ekonomi masyarakat.
\end{abstract}

Kata kunci: degradasi lahan, indeks desa membangun, kuliah kerja nyata, pemberdayaan masyarakat

\begin{abstract}
The objectives of the Defending Country National Priority Village, Community Service Program (KKN) are: 1) Synergize local socio-cultural wisdom with community economic characteristics to prevent degradation of agricultural land through KKN programs, and 2) Formulate strategies to increase the potential of villages towards developed and independent villages. The data collection method is done in two ways, namely primary data obtained by means of surveys, questionnaires, and interviews; secondary data in the form of welldocumented data such as Blitar District in numbers, Kademangan Subdistrict in numbers and reports on village administration or accountability reports on Panggung Duwet Village 2018. Methods of data analysis were carried out using social intervention and SWOT analysis approaches. The results of the implementation of the Defending Country National Priority Village, Community Service Program in Panggungduwet Village, Kademangan Subdistrict are implemented into a work program, namely greening, processing waste into organic fertilizer and crafts, processing food commodities such as corn silk syrup, cassava donuts, and cassava chips. Analysis of the village situation shows that there are still weaknesses, namely the lack of water availability, especially in the dry season for agriculture in line with the opportunities available, namely seeking organic fertilizer by utilizing waste and wood sawdust crafts for sale so that the potential is expected to be a catalyst for village development to become advanced and independent. The existence of the Defending Country National Priority Village, Community Service Community Service Program can leave a good impression so that the community is willing to begin to change the bad behavior of agricultural land management that ignores the rules of conservation and increased knowledge and skills of processed waste and food processing in order to improve the economic welfare of the community.
\end{abstract}


Keywords: community development, land degradation, student study service programs, village development index

\section{PENDAHULUAN}

Degradasi lahan merupakan salah satu masalah yang paling krusial saat sekarang, dan terus meningkat di seluruh dunia, terutama di negara-negara beriklim tropis (Doust et al. 2008) yang masih berkembang (Kertez 2009; Jendoubia et al. 2020). Degradasi lahan adalah proses penurunan produktivitas lahan, baik yang sifatnya sementara maupun tetap. Dampak dari proses degradasi lahan adalah timbulnya lahanlahan yang tidak produktif yang dikenal dengan lahan kritis (Dariah et al. 2004). Sitorus (2011) mengemukakan degradasi lahan yang terjadi dapat berupa berkurangnya produktivitas biologis dan ekonomis lahan, erosi, kerusakan lahan secara fisik/kimia serta kehilangan vegetasi dalam jangka panjang (Pravalie et al. 2017).

Rahadi et al. (2015) menyebutkan perhitungan dan analisis terhadap peta hasil overlay didapatkan bahwa tingkat laju erosi Kabupaten Blitar pada kondisi existing sebesar 116.909 ton/ tahun dengan memiliki erosi rata-rata sebesar 2,67 ton/ha/tahun. Sadesmesli et al. (2017) menyatakan penggunaan lahan aktual di Kabupaten Blitar terdiri atas sebelas kelas dengan penggunaan lahan terluas adalah permukiman 30.860 ha $(19,4 \%)$, sawah 30,564 ha $(19,2 \%)$ dan hutan 30,111 ha $(19,0 \%)$, sedangkan kebun campur dan tegalan mencapai luasan 54,232 ha (34,1\%). Kemampuan lahan terdiri atas enam kelas yaitu kelas II, III, IV, VI, VII, dan VIII yang dapat dibedakan menjadi 15 subkelas. Wilayah yang mampu mendukung aktivitas budi daya pertanian (kelas kemampuan II-IV) hanya sebanyak 61,940 ha (39\% dari luas total), sedangkan wilayah yang sebaiknya tidak digunakan untuk aktivitas budi daya pertanian (kelas VI-VIII) sebanyak 96,939 ha (61\%).

Pengembangan wilayah pedesaan seyogyanya harus didasarkan pada ketersediaan lahan karena prinsipnya lahan merupakan sumber daya utama yang dibutuhkan. Penggunaan lahan harus diarahkan sesuai dengan kemampuan daya dukung perlu dijaga agar tidak terjadi kerusakan atau degradasi. Wang \& Yuheng (2019), menjelaskan restorasi ekologis dan pengelolaan sumber daya lahan yang terdegradasi secara berkelanjutan telah menjadi masalah penting dan mendesak dalam memerangi kemiskinan pedesaan dan memastikan ketahanan pangan. Hubungan erat antara degradasi tanah dan kemiskinan pedesaan seringkali dijumpai (Gray \& Moseley 2005) di mana pengelolaan lahan yang buruk memperburuk kemiskinan, kelaparan, dan kekurangan pangan.

Peningkatan kesejahteraan masyarakat dan desa belakangan ini menggunakan tolak ukur Indeks Desa Membangun (IDM). Upaya mewujudkan desa mandiri dan desa maju merupakan tantangan utama dalam pembangunan desa. IDM dimaksudkan untuk mendukung pencapaian sasaran pembangunan prioritas Rencana Pembangunan Jangka Menengah Nasional (RPJMN) 2015-2019, yaitu mengurangi jumlah desa tertinggal sampai 5.000 desa dan meningkatkan jumlah desa mandiri sedikitnya 2.000 desa di tahun 2019. Sejak diluncurkan kebijakan dana desa, eksistensi desa yang masuk kategori desa mandiri dan desa maju masih relatif kecil (Kemendes PDTT RI 2015). Adapun klasifikasi IDM yang diterbitkan oleh Kemendes PDTT RI dengan kriteria 1) Desa sangat tertinggal $<0,491$; 2) Desa tertinggal: $>0,491$ dan $<0,599$; 3) Desa berkembang: $>0,599$ dan $<0,707$; 4) Desa maju: $>0,707$ dan < 0,815; dan 5) Desa mandiri: > 0,815 .

Desa Panggungduwet merupakan salah satu desa yang ada di Kecamatan Kademangan, Kabupaten Blitar. Desa ini dikategorikan sebagai daerah dataran rendah dengan ketinggian wilayah $\pm 246 \mathrm{mdpl}$. Desa ini dibatasi Sungai Brantas, dengan curah hujan rata-rata sebesar $425 \mathrm{~mm}$, menyebabkan desa ini memiliki potensi wilayah sebagian besar merupakan bergerak di sektor pertanian, namun produktivitas pertanian masih rendah. Hal tersebut disebabkan karena menghadapi berbagai permasalahan di antaranya belum tercukupinya kebutuhan pupuk, termasuk kurangnya pemahaman teknologi pengelolaan tanah secara tepat dan rendahnya produktivitas lahan karena lahan terdegradasi.

Desa Panggungduwet dalam klasifikasi tipologi desa menurut IDM tergolong desa berkembang dengan nilai IDM sebesar 0,59 yang diartikan masih perlunya upaya meningkatkan taraf perekonomian desa sekaligus kesejahteraan masyarakat sehingga menjadi desa maju dan mandiri. Peningkatan status desa, dari desa berkembang menjadi mandiri maupun maju, membutuhkan pembinaan mulai dari aspek sarana prasarana, hingga peningkatan kualitas sumber daya manusia. 
Kuliah Kerja Nyata Belanegara Desa Prioritas Nasional merupakan salah satu cara untuk mengembangkan kepekaan rasa, cara berpikir, dan bekerja secara lintas disiplin ilmu dan lintas sektoral bagi mahasiswa. Selain itu, program KKN dengan metode pendekatan pemberdayaan masyarakat melalui difusi inovasi teknologi tepat guna (TTG), merupakan solusi efektif, praktis, dan bernilai ekonomis dalam memecahkan masalah masyarakat.

Berdasarkan uraian permasalahan yang telah dikemukakan, Desa Panggung Duwet diidentifikasi memiliki karakteristik mengalami degradasi lahan dan tergolong desa berkembang menurut klasifikasi IDM. Oleh karena itu, dalam hal pembangunan desa maka instrumen penting perlu diketahui adalah bagaimana sebenarnya kelemahan dan ancaman yang dihadapi serta sebaliknya kekuatan dan peluang dari potensi desa yang dimiliki. Tujuan program kegiatan KKN Bela Negara Desa Prioritas Nasional ini dilakukan adalah 1) Mensinergikan kearifan lokal sosial budaya dengan karakteristik perekonomian masyarakat untuk pencegahan degradasi lahan pertanian melalui program KKN dan 2) Merumuskan strategi untuk meningkatkan potensi desa menuju desa maju dan mandiri.

\section{METODE PELAKSANAAN KEGIATAN}

\section{Tempat dan Waktu Kegiatan}

Kegiatan KKN Bela Negara Desa Prioritas Nasional dilaksanakan di Desa Panggung Duwet, Kecamatan Kademangan, Kabupaten Blitar. Dipilihnya desa tersebut secara sengaja (purposive) dengan pertimbangan tergolong desa berkembang sesuai data Indeks Desa Membangun (IDM), yaitu sebesar 0,59. Angka ini menunjukkan perlunya upaya meningkatkan taraf perekonomian desa sekaligus kesejahteraan masyarakat sehingga menjadi desa maju dan mandiri. Pelaksanaan kegiatan KKN Bela Negara Desa Prioritas Nasional dilakukan mulai tanggal 25 Juli-8 Agustus 2018. Program KKN ini merupakan bentuk perwujudan dari usulan skim hibah mandiri KKN Tematik UPN "Veteran" Jawa Timur dengan judul "Pemberdayaan Ekonomi Masyarakat dan Edukasi Pola Hidup Sehat Menuju Desa Mandiri “.

\section{Metode Pengumpulan Data}

- Data primer. Pengumpulan data primer dilakukan dengan cara survei, kuesioner, dan wawancara dengan sekretaris desa, perangkat desa, tokoh masyarakat, kelompok tani, dan warga masyarakat sekitar Desa Panggungduwet yang berkaitan dengan progam kerja yang dilakukan oleh peserta KKN. Data yang telah didapatkan akan menjadi masukan untuk peserta KKN tematik untuk mendukung proses berjalannya progam kerja yang ditentukan.

- Data Sekunder. Pengumpulan data sekunder berupa data yang terdokumentasi secara baik seperti Kabupaten Blitar dalam angka, Kecamatan Kademangan dalam angka maupun laporan penyelenggaraan pemerintahan desa dan atau laporan keterangan pertanggungjawaban Desa Panggungduwet Tahun 2018.

\section{Metode Analisis Data}

\section{- Metode intervensi sosial}

Menjawab tujuan pelaksanaan program KKN yang pertama adalah mensinergikan kearifan lokal sosial budaya dengan karakteristik perekonomian masyarakat sebagai upaya optimalisasi pencegahan degradasi lahan pertanian digunakan pendekatan metode intervensi sosial. Adi (2005) menyatakan intervensi sosial merupakan metode yang digunakan untuk melakukan kegiatan sosial atau kesejahteraan sosial. Terdapat tiga aspek dalam melakukan intervensi sosial dan mengidentifikasi masalah atau kebutuhan dalam melakukan perubahan sosial, yaitu: masalah, populasi, dan arena (Suharto 2007). Masalah adalah melakukan identifikasi masalah dengan mempelajari literatur dan teori yang relevan. Wawancara merupakan strategi yang tepat untuk melakukan identifikasi masalah. Sebagaimana sebelum melakukan KKN, kami melakukan wawancara kepada warga mengenai masalah degradasi lahan termasuk potensi desa. Populasi adalah mempelajari literatur untuk mengetahui sebanyak mungkin populasi yang terkena masalah. Melalui wawancara dengan para tokoh masyarakat (organisasi) akan memberikan pandangan tersendiri mengenai permasalahan yang ada. Arena adalah mempelajari literatur untuk mempelajari aspek-aspek demografis dan data lainnnya mengenai organisasi atau masyarakat.

Berdasarkan dari hasil survei yang dilakukan pada saat sebelum melaksanakan kegiatan KKN, wawancara dengan masyarakat dan hasil kesepakatan dari kelompok KKN beserta dengan dosen pembimbing, maka strategi intervensi 
yang dilakukan adalah melalui program-program pengembangan masyarakat yang bersifat pembangunan lokal, yaitu berbentuk usaha ekonomi produktif dan penerapan teknologi tepat guna berasal dari kearifan lokal Desa Panggungduwet.

\section{- Analisis SWOT strategi penguatan potensi desa}

Langkah utama dalam analisis lingkungan menekankan kekuatan dan kelemahan yang berasal dari lingkungan internal suatu desa dan sekaligus adanya peluang dan ancaman dari lingkungan eksternalnya. Analisis lingkungan internal lebih mengedepankan faktor-faktor yang ada didalam desa itu sendiri seperti sumber daya alam, potensi komoditas unggulan pertanian, maupun potensi masyarakatnya.

Kekuatan (strenght) adalah kekuatan pada keunggulan kedudukan dipasar, hubungan antarmasyarakat, dan kepercayaan pemerintah desa. Sebagai produk andalan para pesaing dalam memuaskan kebutuhan pasar yang sudah direncanakan akan dilayani oleh satuan usaha yang bersangkutan. Kelemahan (weakness) adalah keterbatasan atau kekurangan dalam hal sumber, ketrampilan dan kemampuan yang menjadi peluang serius bagi penampilan yang memuaskan. Peluang (opportunity) adalah berbagai situasi lingkungan yang menguntungkan suatu wilayah, perubahan kondisi persaingan, hubungan dengan pemasok yang harmonis. Ancaman (threat) adalah lingkungan yang tidak menguntungkan suatu desa, seperti adanya pesaing, pertumbuhan pasar yang lambat, dan meningkatkan posisi tawar pembeli produk. Dengan demikian dapat dikatakan bahwa ancaman adalah faktor-faktor lingkungan yang tidak menguntungkan suatu wilayah (Rangkuti 2014).

\section{HASIL DAN PEMBAHASAN}

\section{Mensinergikan Kearifan Lokal Sosial Budaya dengan Karakteristik Perekonomian Masyarakat untuk Pencegahan Degradasi Lahan}

Upaya mendorong perekonomian lokal adalah mendorong pengembangan tingkat desa berbasis pada kearifan lokal, potensi sumber daya dan keunikannya, dengan inovasi menjadi kunci pengembangannya. Inovasi yang dimaksud adalah upaya menciptakan cara, proses, dan produk baru yang memberikan nilai tambah bagi kehidupan dan kesejahteraan masyarakat. Desa inovatif adalah desa yang warga masyarakatnya mampu mengenali dan mengatasi serta memanfaatkan teknologi atau cara-cara baru untuk mengatasi masalah dan meningkatkan perekonomiannya dengan cara menggunakan teknologi yang ada di sekitar lingkungannya secara mandiri.

\section{- Inovasi penghijauan}

Desa Panggungduwet yang terletak di Kecamatan Kademangan mempunyai struktur tanah sangat kering dan kurang subur. Kondisi lahan kering karena di daerah dataran tinggi (pegunungan) dan struktur tanahnya kurang subur dan berbatu (jenis tanah regosol). Desa Panggungduwet mengalami dua musim pada setiap tahunnya, yaitu musim penghujan dan musim kemarau. Ketersediaan air di Desa Panggungduwet masih belum mencukupi terutama pada musim kemarau.

Sumber air merupakan salah satu elemen utama kehidupan bagi masyarakat Desa Panggungduwet. Sumber air dapat dimanfaatkan untuk memenuhi kebutuhan air sehari-hari, mulai dari air sanitasi hingga air minum. Desa Panggungduwet sendiri memiliki delapan titik sumber air yang tersebar dengan kondisi yang berbeda-beda. Hanya beberapa titik saja yang dapat dimanfaatkan oleh masyarakat sekitar. Menurunnya debit air pada sumber-sumber yang ada di Desa Panggungduwet disebabkan oleh pengalihan lahan penghijauan menjadi lahan produksi dan ekosistem di sekitar sumber air yang rusak.

Reboisasi merupakan inovasi untuk mengatasi permasalahan yang ada di Desa Panggungduwet (Gambar 1) yang bertujuan untuk membangun kembali ekosistem alam di sekitar desa. Penghijauan yang akan di lakukan pada dua titik sumber air yang terletak di Dusun Panggung Rejo. Jenis pohon yang akan digunakan

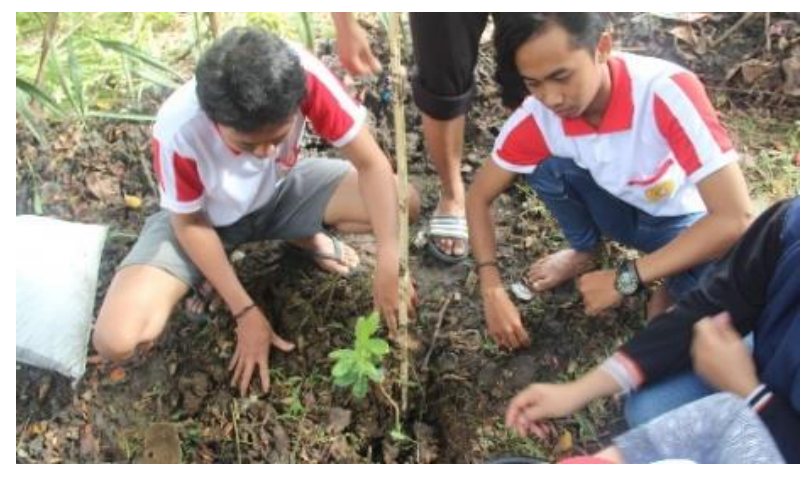

Gambar 1 Kegiatan reboisasi. 
antara lain seperti bibit pohon jati, sengon, dan kesambi. Masing-masing bibit pohon berumur 12 bulan dengan jumlah pohon yang akan ditanam sebanyak 90 bibit yang disediakan oleh Perhutani Kota Blitar.

Lokasi pertama yang akan dilakukan penghijauan terletak di Dusun Panggung Rejo 2 km dari Balai Desa Panggungduwet. Kondisi sumber air saat ini adalah debit air yang menurun drastis, lahan gundul di sekitar sumber air, dan pengalihan lahan penghijauan menjadi lahan produktif. Jenis bibit pohon yang akan ditanam adalah pohon kesambi. Lokasi kedua yang akan dilakukan penghijauan terletak di Dusun Krajan 500 m dari Balai Desa Panggungduwet. Kondisi sumber air saat ini adalah debit air yang menurun, lingkungan di sekitar sumber air yang kotor, dan terdapat banyak sampah plastik. Lokasi ketiga merupakan tanah kas desa yang akan dilakukan penghijauan. Terletak di Dusun Panggung Rejo $1 \mathrm{~km}$ dari Balai Desa Panggungduwet. Penghijauan dilakukan di sekitar tandon desa. Jenis bibit pohon yang akan ditanam adalah pohon jati dan sengon.

\section{- Inovasi pengelolaan sampah}

Mata pencaharian masyarakat di Desa Panggungduwet sebagian besar adalah petani dan peternak. Salah satu komoditas pertanian tanaman pangan unggulan antara lain ketela pohon dan jagung. Setiap harinya para petani dan peternak menghasilkan banyak limbah seperti sisa sekam, kotoran sapi, dan akar bambu. Limbah-limbah yang di hasilkan masyarakat di Desa Panggungduwet dapat dimanfaatkan sebagai bahan pembuatan pupuk organik. Pupuk organik yang dihasilkan dapat digunakan sebagai pupuk di lahan-lahan pertanian yang dapat meningkatkan hasil penan para petani.

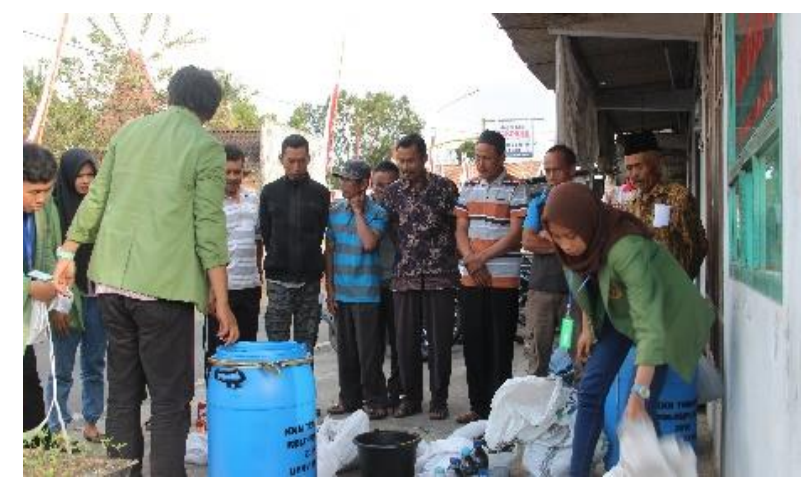

a
Petani di Desa Panggung Duwet sudah pernah membuat pupuk organik namun mereka menilai bahwa pembuatan pupuk organik membutuhkan waktu dan proses yang panjang dalam pembuatannya. Pupuk organik juga dinilai tidak memiliki pengaruh yang cukup besar terhadap pertumbuhan tanaman. Petani cenderung menyukai hal-hal yang berdampak instan dari penggunaan pupuk kimia. Namun demikian, sebagaian besar dari petani menganggap banyak di antara mereka yang rentan sakit karena penggunaan dosis pupuk kimia yang berlebihan dan struktur tanah yang semakin keras dan sulit untuk ditanami kembali. Hal ini menunjukkan untuk menjaga kesehatan sekaligus kelestarian lingkungan mulai dipikirkan di Desa Panggungduwet.

Pada prinsipnya tanaman membutuhkan berbagai unsur hara seperti N, P, dan K. Berbagai sumber daya yang dapat digunakan untuk menyediakan nutrisi pada pupuk cair tersedia di Desa Panggungduwet. Sumber nitrogen (N) didapatkan dari daun lamtoro dan urin sapi. Apabila tidak terdapat urin sapi maka dapat digantikan dengan daun-daunan yang berasal dari famili leguminosa (kacang-kacangan) dan tanaman pisang. Bagian yang dapat digunakan sebagai sumber $\mathrm{N}$ adalah hati pisang dan bonggol. Sumber fosfor (P) didapatkan dari buah busuk. Pohon belimbing dapat dimanfaatkan buahnya sebagai sumber $P$ yang terdapat di Desa Panggungduwet. Sumber kalium (K), didapatkan dari bekas bakaran sekam padi yang dihasilkan dari sisa panen warga dan dapat juga ditambahkan dengan akar bambu. Gambar 2 menunjukkan demo pembuatan pupuk organik cair kepada masyarakat dan produk pupuk organik cair yang dihasilkan.

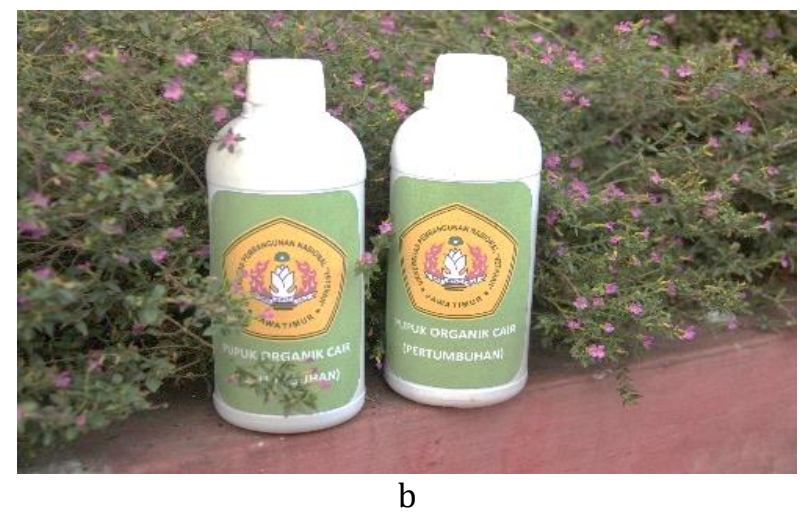

Gambar 2 a)Demo pembuatan pupuk organik cair kepada masyarakat dan b) Produk pupuk organik cair yang dihasilkan. 


\section{- Inovasi teknologi tepat guna}

Salah satu komoditas utama di Desa Panggungduwet adalah ketela pohon. Selain menjual hasil panen ketela pohon, masyarakat juga mengolah ketela pohon menjadi nasi tiwul, gatot, dan olahan keripik. Pengolahan keripik yang dilakukan secara tradisional menghasilkan produk kripik yang kurang renyah karena diproduksi secara manual. Pengolahan kripik yang modern dapat meningkatkan hasil produksi yang banyak dan lebih cepat dalam proses produksi. Alat pemotong keripik singkong dapat membantu proses pemotongan lebih cepat, mudah, dan praktis. Hasil potongan yang seragam dan kemiliki ketebalan yang pas merupakan unggulan dari alat tersebut. Produk yang dihasilkan lebih renyah dan memiliki bentuk yang seragam. Alat pemotong singkong yang merupakan hasil dari TTG terlihat pada Gambar 3.

\section{- Inovasi olahan limbah serbuk kayu}

Banyak masyarakat di Desa Panggungduwet yang bekerja sebagai pengrajin kayu untuk perabotan rumah tangga, sehingga banyak menghasilkan limbah berupa serbuk kayu yang melimpah. Limbah serbuk kayu yang dihasilkan dapat dijual dengan harga Rp 2.000-5.000 per sak. Pengrajin kayu tidak berminat untuk menjual limbah dengan harga tersebut karena harga yang terlalu murah dan kendala transportasi untuk memasarkan ke kota. Kurangnya sosialisasi tentang cara mengolah limbah serbuk kayu juga merupakan masalah dari melimpahnya limbah serbuk kayu. Selama ini serbuk kayu hanya digunakan untuk bahan bakar tungku dan untuk membakar sisa panen.

Penanggulangan limbah serbuk kayu dilakukan dengan mengubahnya menjadi kerajinan. Serbuk kayu dapat dijadikan sebagai kerajinan seperti puzzle, bingkai foto, dan pot untuk tanaman indoor (Gambar 4). Kerajinan yang sudah jadi dapat menghasilkan barang yang bernilai ekonomis lebih tinggi daripada menjual serbuk kayu yang belum diolah.

\section{- Inovasi olahan pangan jagung}

Desa Panggungduwet memiliki hasil melimpah pada produksi komoditas jagung. Masyarakat di Desa Panggungduwet menanam jagung saat musim kemarau dalam setahun sebanyak satu kali di lahan sawah. Setelah dipanen jagung diolah oleh masyarakat menjadi nasi jagung. Hal ini yang menyebabkan perekonomian di Desa Panggungduwet tergolong rendah. Inovasi produk olahan jagung yang ditawarkan kepada masyarakat Desa Panggungduwet sebagai upaya memperkaya hasil olahan jagung antara lain pembuatan sirup rambut jagung (Gambar 5) dan pudding jagung.

Zea mays L. atau lebih dikenal dengan nama jagung merupakan tanaman yang banyak dikenal masyarakat. Tanaman ini tersebar luas, terutama di Jawa, pada ketinggian 200 mdpl. Bagian-bagian tanaman jagung telah banyak dimanfaatkan oleh masyarakat sebagai obat tradisional, salah satunya adalah bagian rambut jagung yang merupakan limbah industri pangan. Ekstrak air rambut jagung menunjukan hasil positif untuk penyembuhan gagal ginjal pada tikus.

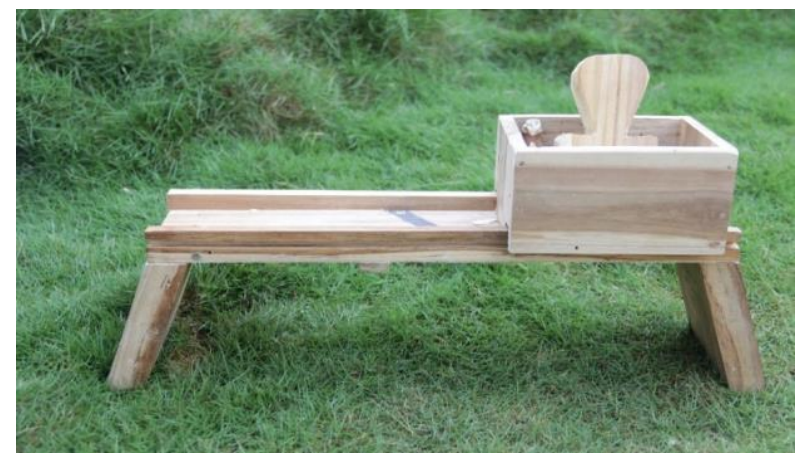

Gambar 3 Teknologi tepat guna (alat pemotong singkong).

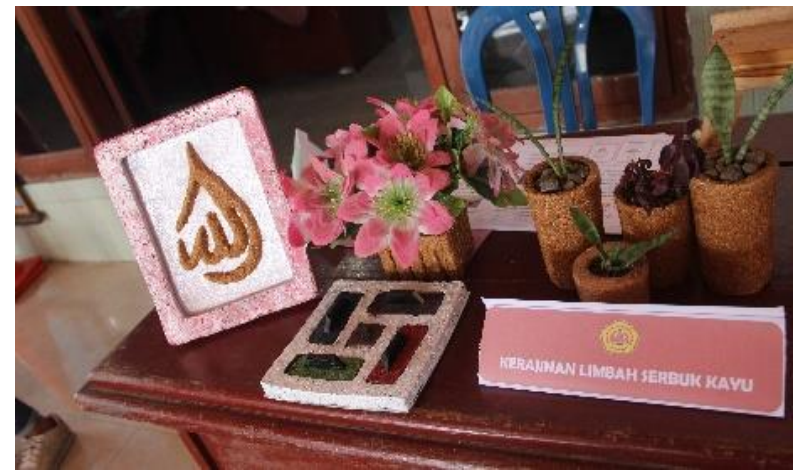

Gambar 4 Berbagai kreasi handicraft olahan limbah serbuk kayu.

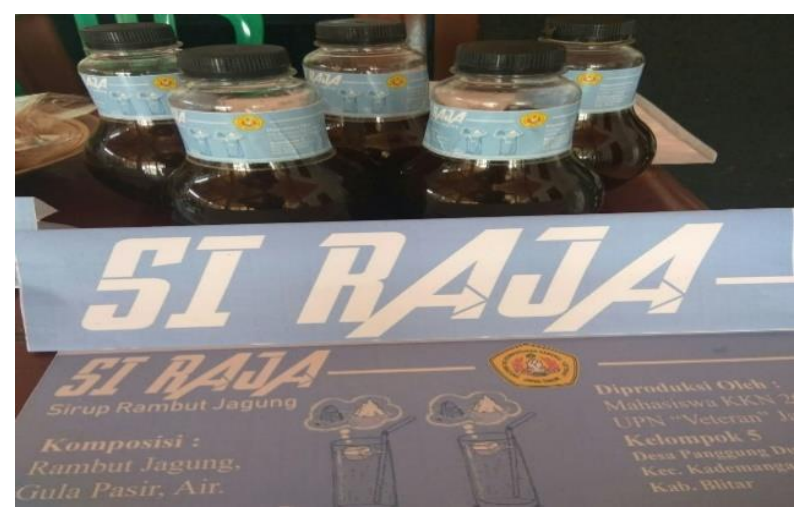

Gambar 5 “SI RAJA” sirup rambut jagung. 
Saat ini rambut jagung belum dimanfaatkan oleh masyarakat secara maksimal. Salah satu kandungan di dalam rambut jagung yang dapat digunakan untuk menurunkan kadar kolesterol dalam darah adalah ß-sitosterol, karena ßsitosterol termasuk zat hipokolesterolemik. Rambut jagung memiliki manfaat dalam pengobatan. Hal ini dikarenakan rambut jagung memiliki kandungan senyawa kimia yang berguna bagi kesehatan. Selain itu rambut jagung juga bermanfaat untuk mengobati batu ginjal dan menurunkan hipertensi.

Jagung juga dapat diolah menjadi pudding. Selain rasanya yang enak, pudding jagung juga dapat digunakan sebagai makanan yang dapat disuguhkan untuk acara-acara yang ada di Desa Panggungduwet, sehingga para ibu-ibu bisa menurangi pembelian bahan untuk suguhan dengan memanfaatkan jagung yang berlimpah di desa tersebut.

\section{- Inovasi olahan pangan singkong}

Desa Panggungduwet memiliki hasil melimpah pada produksi komoditas singkong. Masyarakat di Desa Panggungduwet menanam singkong di lahan tegalan milik mereka. Singkong yang ditanam di Desa Panggungduwet terdiri dari 2 jenis, yaitu singkong hitam yang keras dan lembut. Singkong yang keras dijemur dan dijadikan tepung untuk bahan membuat nasi tiwul dan gatot. Singkong yang lembut dapat dijadikan produk olahan makanan, sehingga bisa dilakukan inovasi produk makanan yang dapat diolah dari produk tersebut. Tidak sebatas inovasi pengolahan produk saja untuk meningkat perekonomian masyarakat tetapi perlu adanya edukasi terkait bagaimana cara pemasaran produk olahan yang baru yang nantinya dijadikan produk unggulan dari Desa Panggungduwet agar

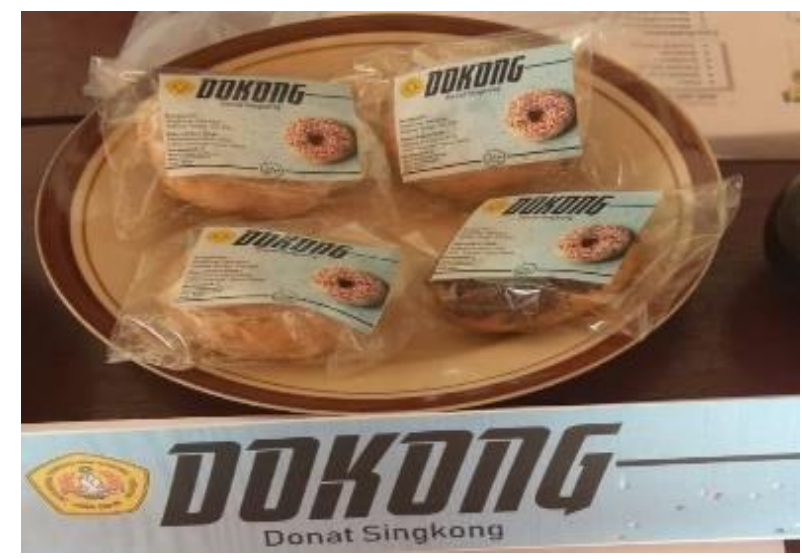

a produk mereka bisa terpasarkan secara global sehingga perekonomian mereka juga bisa terangkat. Masyarakat di Desa Panggungduwet sebenarnya tidak sepenuhnya gagap teknologi, mereka sudah memiliki kemampuan untuk mengoperasikan smartphone. Namun belum bisa memaksimalkan fungsi gadget untuk memasarkan produk dari komoditas utama.

Inovasi produk olahan singkong yang dibuat di Desa Panggungduwet antara lain donat singkong dan keripik singkong (Gambar 6). Donat singkong terbuat dari bahan dasar singkong atau ubi kayu yang memiliki tekstur sangat empuk dan lembut. Donat singkong bisa disajikan pada acara-acara seperti pengajian, arisan, pernikahan, dan lain sebagainya. Selain memiliki tekstur yang empuk dan lembut dimulut, makanan ini juga memiliki rasa manis yang pas dan juga termasuk dalam golongan makanan sehat.

Singkong yang lembut juga dapat dijadikan keripik dengan cara digoreng biasa dan diberi varian bumbu. Inovasi yang digunakan pada pembuatan keripik singkong adalah alat pemotong, sehingga memudahkan para pengusaha keripik singkong untuk memotong singkong lebih cepat dan lebih mudah.

\section{Strategi Peningkatan Potensi Desa menuju Desa Maju dan Mandiri}

Strategi pengembangan pedesaan berkaitan dengan persoalan bagaimana mengubah sesuatu kebiasaan tradisional masyarakat desa. Desa juga sebagai basis suatu sumber daya ekonomi, basis komunitas yang mempunyai keberagaman nilainilai lokal dan ikatan-ikatan sosial, maupun basis kepemerintahan yang mengatur dan mengurus sumber daya dan komunitas tersebut. Oleh karenanya desa memiliki segudang potensi yang

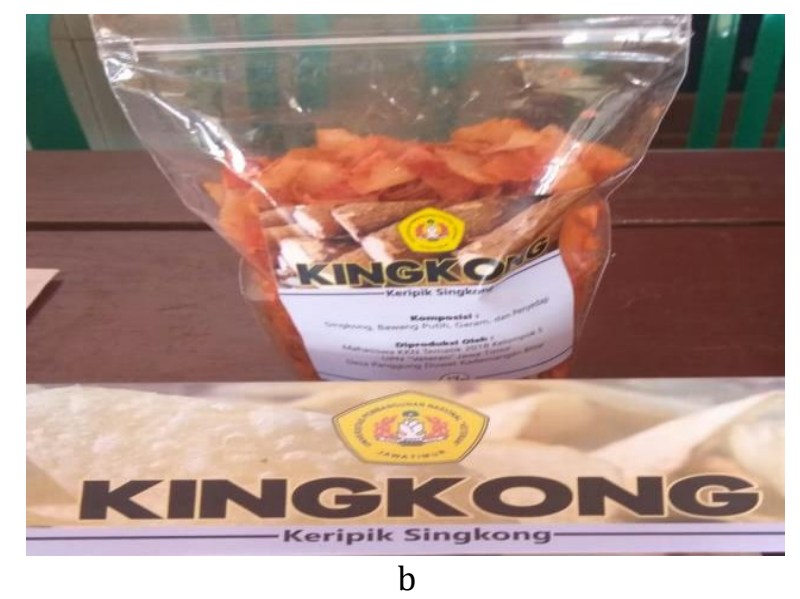

Gambar 6 a) "DOKONG" donat singkong dan b) "KINGKONG" keripik singkong. 
bisa diangkat menjadi komoditas dan dipoles dengan manajemen strategi yang tepat menuju kemandirian desa.

\section{- Identifikasi potensi lingkungan internal}

Menentukan isu strategis dan strategi pengembangan digunakan analisis SWOT (Strenght, Weakness, Opportunity and Threat). Faktor-faktor yang diperkirakan berpengaruh terhadap pembangunan Desa Panggungduwet, Kecamatan Kademangan, Kabupaten Blitar dipilah menjadi dua kelompok besar, yaitu kelompok faktor internal dan eksternal. Kelompok faktor internal terbagi dalam dua kategori, yaitu faktor kekuatan dan kelemahan. Pengelompokkan tersebut didasarkan program kerja yang telah disusun oleh peserta mahasiswa KKN Bela Negara Desa Prioritas Nasional Secara ringkas lingkungan internal dimiliki oleh Desa Panggungduwet terdiri atas faktor kekuatan dan kelemahan dapat diuraikan pada Tabel 1 dan 2 .

Identifikasi faktor kekuatan (Tabel 1) menempatkan pernyataan "desa memiliki kelompok pertanian (Poktan)" dan "melimpahnya limbah rumah tangga (buah-buahan, dedaunan, sisa panen, dan kotoran sapi)" yang diidentifikasi oleh Kelompok Divisi Pengolahan Limbah memiliki nilai tertinggi menurut persepsi responden. Selain itu, juga diketahui bahwa pernyataan "tersedia sumber daya manusia (petani, peternak, pengrajin, tukang kayu, dan tukang batu)" dari hasil identifikasi Kelompok Divisi Lingkungan. Apabila digeneralisasikan maka ketiga pernyataan tersebut menjadi indikator kekuatan yang ada di Desa Panggung Duwet, Kecamatan Kademangan, Kabupaten Blitar

Tabel 1 Identifikasi faktor kekuatan (strenght) Desa Panggungduwet berdasar program kerja KKN Bela Negara Desa Prioritas Nasional

\begin{tabular}{|c|c|c|c|c|}
\hline Program kerja & Uraian & Skor & Bobot & Nilai \\
\hline \multirow{5}{*}{ Lingkungan } & $\begin{array}{l}\text { Tersedia sumber daya manusia (petani, peternak, pengrajin, } \\
\text { tukang kayu, dan tukang batu). }\end{array}$ & 4 & 0,08 & 0,32 \\
\hline & $\begin{array}{l}\text { Siklus dan ritme kehidupan warga masyarakat yang dari masa } \\
\text { ke masa relatif teratur dan terjaga adatnya }\end{array}$ & 2 & 0,07 & 0,14 \\
\hline & $\begin{array}{l}\text { Hubungan yang baik dan kondusif antara kepala desa, pamong } \\
\text { desa, dan masyarakat merupakan kondisi yang idial untuk } \\
\text { terjadinya pembangunan desa }\end{array}$ & 3 & 0,06 & 0,18 \\
\hline & Lahan desa yang belum dimanfaatkan secara optimal & 3 & 0,07 & 0,21 \\
\hline & $\begin{array}{l}\text { Desa merupakan daerah perbukitan dengan pemandangan } \\
\text { indah }\end{array}$ & 3 & 0,06 & 0,18 \\
\hline \multirow{5}{*}{$\begin{array}{l}\text { Pengolahan } \\
\text { limbah }\end{array}$} & Melimpahnya limbah serbuk kayu & 3 & 0,06 & 0,18 \\
\hline & Desa memiliki kelompok aktif ibu-ibu PKK dan pengajian & 3 & 0,07 & 0,21 \\
\hline & $\begin{array}{l}\text { Olahan limbah serbuk kayu masih sedikit pesaing dengan desa } \\
\text { lain }\end{array}$ & 3 & 0,05 & 0,15 \\
\hline & Desa memiliki kelompok pertanian (POKTAN) & 4 & 0,08 & 0,32 \\
\hline & $\begin{array}{l}\text { Melimpahnya limbah rumah tangga (buah-buahan, dedaunan, } \\
\text { sisa panen dan kotoran sapi) }\end{array}$ & 3 & 0,08 & 0,24 \\
\hline \multirow{4}{*}{$\begin{array}{l}\text { Olahan } \\
\text { pangan }\end{array}$} & $\begin{array}{l}\text { Desa memiliki komoditas unggulan pertanian (jagung dan } \\
\text { ketela pohon) yang belum dioptimalkan diversifikasi pangan }\end{array}$ & 4 & 0,05 & 0,20 \\
\hline & Kandungan rambut jagung untuk kesehatan & 3 & 0,06 & 0,18 \\
\hline & $\begin{array}{l}\text { Jenis ketela pohon hitam dengan tekstur daging lembut } \\
\text { dibudidayakan }\end{array}$ & 3 & 0,04 & 0,12 \\
\hline & $\begin{array}{l}\text { Desa memiliki potensi kayu melimpah, dapat digunakan alat } \\
\text { pemotong singkong sederhana }\end{array}$ & 3 & 0,05 & 0,15 \\
\hline \multirow{2}{*}{ Pendidikan } & Pemerintahan desa fokus terhadap peningkatan pendidikan & 4 & 0,04 & 0,16 \\
\hline & Terdapat bangunan sekolah dan TPQ & 3 & 0,04 & 0,12 \\
\hline \multirow{5}{*}{$\begin{array}{l}\text { Administrasi } \\
\text { desa }\end{array}$} & $\begin{array}{l}\text { Desa memiliki bangunan balai desa untuk pelayanan } \\
\text { masyarakat }\end{array}$ & 4 & 0,05 & 0,20 \\
\hline & Desa telah terbentuk perangkat desa & 3 & 0,06 & 0,18 \\
\hline & $\begin{array}{l}\text { Balai desa dilengkapi alat-alat perkantoran termasuk } \\
\text { komputer }\end{array}$ & 3 & 0,07 & 0,21 \\
\hline & $\begin{array}{l}\text { Kepala desa telah menetapkan tugas, pokok dan fungsi masing- } \\
\text { masing perangkat desa }\end{array}$ & 3 & 0,05 & 0,15 \\
\hline & Jumlah & & 1,19 & 3,80 \\
\hline
\end{tabular}

Sumber: Hasil analisis data (2019) 
Tabel 2 Identifikasi faktor kelemahan (weakness) Desa Panggungduwet berdasar program kerja KKN Bela Negara Desa Prioritas Nasional

\begin{tabular}{|c|c|c|c|c|}
\hline Bidang & Uraian & Skor & Bobot & Nilai \\
\hline \multirow{7}{*}{ Lingkungan } & $\begin{array}{l}\text { Kurangnya kesediaan air bersih, terutama di musim } \\
\text { kemarau }\end{array}$ & 4 & 0,08 & 0,32 \\
\hline & Kurangnya kesadaran warga untuk hidup bersih & 4 & 0,07 & 0,28 \\
\hline & Kurang baiknya sarana sanitasi rumah/lingkungan & 3 & 0,06 & 0,18 \\
\hline & Lahan marjinal & 4 & 0,07 & 0,28 \\
\hline & $\begin{array}{l}\text { Tekstur tanahnya kurang subur dan berbatu (jenis } \\
\text { tanah antisol) }\end{array}$ & 4 & 0,06 & 0,24 \\
\hline & $\begin{array}{l}\text { Pembuatan pupuk organik yang membutuhkan waktu } \\
\text { relatif lama }\end{array}$ & 3 & 0,08 & 0,24 \\
\hline & Kurangnya debit air pertanian & 4 & 0,07 & 0,28 \\
\hline \multirow{3}{*}{$\begin{array}{l}\text { Pengolahan } \\
\text { limbah }\end{array}$} & $\begin{array}{l}\text { Proses pengeringan produk kerajinan limbah gergaji } \\
\text { kayu, mencapai } 4 \text { hari }\end{array}$ & 3 & 0,06 & 0,18 \\
\hline & Pupuk organik tidak me-recovery lahan secara cepat & 3 & 0,07 & 0,21 \\
\hline & Masih banyak warga tidak terbuka dengan inovasi baru & 3 & 0,05 & 0,15 \\
\hline \multirow{5}{*}{$\begin{array}{l}\text { Olahan } \\
\text { pangan }\end{array}$} & Rusaknya jalur transportasi keluar desa & 3 & 0,05 & 0,15 \\
\hline & Rasa sirup rambut jagung tidak terasa jagungnya Hanya & & & \\
\hline & $\begin{array}{l}\text { Terasa baunya karena hanya menggunakan rambut } \\
\text { jagungnya }\end{array}$ & 3 & 0,06 & 0,18 \\
\hline & Masih memandang rambut jagung sebagai sampah & 3 & 0,04 & 0,12 \\
\hline & Olahan singkong hanya sebagai nasi tiwul & 3 & 0,05 & 0,15 \\
\hline \multirow{3}{*}{ Pendidikan } & Rendah dan kurangnya kesadaran pendidikan formal & 4 & 0,04 & 0,16 \\
\hline & Masih sedikit anak-anak yang tidak bisa mengaji & 4 & 0,04 & 0,16 \\
\hline & Sedikit bangunan sekolah dan TPQ & 3 & 0,04 & 0,12 \\
\hline \multirow{4}{*}{$\begin{array}{l}\text { Administrasi } \\
\text { desa }\end{array}$} & Seringnya perangkat desa tidak ditempat & 4 & 0,05 & 0,20 \\
\hline & Kurang kejelasan alur administrasi warga & 3 & 0,06 & 0,18 \\
\hline & $\begin{array}{l}\text { Banyak perangkat desa yang tidak bisa } \\
\text { Mengoperasionalkan komputer }\end{array}$ & 4 & 0,07 & 0,28 \\
\hline & Jumlah & & 1,17 & 4,06 \\
\hline
\end{tabular}

Sumber: Hasil analisis data (2019).

menjadikannya desa maju dan mandiri. Berbeda halnya dengan faktor kelemahan yang menempatkan pernyataan "kurangnya kesediaan air bersih, terutama di musim kemarau" merupakan indikator utama sebagai kelamahan Desa Panggung Duwet dari hasil identifikasi Kelompok Divisi Lingkungan (Tabel 2).

\section{- Identifikasi Potensi Lingkungan Eksternal}

Analisis lingkungan eksternal mencangkup pemahaman berbagai faktor di luar Desa Panggungduwet yang mengarah pada munculnya peluang bahkan ancaman bagi bukan hanya aparatur pemerintahan desanya tetapi masyarakat yang tinggal di sana. Bagi pengembangan strategik, analisis ini dibutuhkan tidak hanya terbatas pada rincian analisis kesempatan dan ancaman saja tetapi juga untuk menentukan dari mana dan untuk apa hasil analisis itu di pergunakan. Adapun lingkungan eksternal Desa Panggungduwet yang mencakup faktor peluang dan ancaman dapat diuraikan pada Tabel 3 dan 4 .
Berdasarkan Tabel 3 dapat diketahui bahwa "mengupayakan pupuk organik dengan memanfaatkan limbah", "kerajinan limbah gergaji kayu dijual dalam bentuk souvenir pernikahan" dan "terbukanya destinasi wisata alam baru" merupakan peluang yang dimiliki oleh Desa Panggungduwet, Kecamatan Kademangan, Kabupaten Blitar dalam meningkatkan potensi desa menjadi desa maju dan mandiri. Sebaliknya, ancaman yang dihadapi di antaranya digambarkan pada pernyataan "sifat pemalas petani untuk pembuatan pupuk organik secara berkala" dan "kurang kompaknya antar warga, sehingga sering menimbulkan gesekan dan konflik kepentingan" dari hasil identifikasi Kelompok Divisi Pengolahan Limbah dan Olahan Pangan. Hasil ini sekaligus menggambarkan kondisi riil bahwa selama ini perangkat desa mendapat tantangan dari konflik warga yang terjadi secara terus menerus sehingga kedepan perlu kesepahaman bersama dengan masyarakat untuk mengurangi permasalahan sosial tersebut dan mampu mewujudkan desa maju dan mandiri. 
Tabel 3 Identifikasi faktor peluang (opportunity) Desa Panggungduwet berdasar program kerja KKN Bela Negara Desa Prioritas Nasional.

\begin{tabular}{|c|c|c|c|c|}
\hline Bidang & Uraian & Skor & Bobot & Nilai \\
\hline \multirow{5}{*}{ Lingkungan } & $\begin{array}{l}\text { Desa Panggung Duwet sendiri memiliki } 8 \text { titik sumber air yang tersebar } \\
\text { dengan kondisi yang berbeda-beda }\end{array}$ & 3 & 0,08 & 0,24 \\
\hline & $\begin{array}{l}\text { Lahan perkebunan dan pekarangan yang subur, belum dikelola secara } \\
\text { maksimal }\end{array}$ & 2 & 0,07 & 0,14 \\
\hline & $\begin{array}{l}\text { Lahan pertanian (sawah) yang masih dapat ditingkatkan } \\
\text { produktifitasnya dan berkelanjutan }\end{array}$ & 2 & 0,06 & 0,12 \\
\hline & $\begin{array}{l}\text { Memanfaatkan lahan tidur yang ada dengan tanaman keras dan } \\
\text { tumpangsari lainnya (polowijo) }\end{array}$ & 3 & 0,07 & 0,21 \\
\hline & $\begin{array}{l}\text { Bekerjasama dengan Dinas Kehutanan dan Perkebunan di dalam } \\
\text { Melestarikan Lingkungan Hidup }\end{array}$ & 3 & 0,06 & 0,18 \\
\hline \multirow{4}{*}{$\begin{array}{l}\text { Pengolahan } \\
\text { limbah }\end{array}$} & $\begin{array}{l}\text { Adanya kelembagaan, organisasi, dan kelompok-kelompok, pertanian, } \\
\text { usaha dan keagamaan desa, memudahkan dalam berkoordinasi setiap } \\
\text { kegiatan pembangunan }\end{array}$ & 2 & 0,06 & 0,12 \\
\hline & Mengupayakan pupuk organik dengan memanfaatkan limbah & 3 & 0,12 & 0,36 \\
\hline & Kerajinan limbah gergaji kayu dijual dalam bentuk souvenir pernikahan & 3 & 0,10 & 0,30 \\
\hline & Terbukanya destinasi wisata alam baru & 3 & 0,10 & 0,30 \\
\hline \multirow{5}{*}{ Olahan pangan } & $\begin{array}{l}\text { Meningkatkan keterampilan usaha melalui pelatihan-pelatihan } \\
\text { kewirausahaan }\end{array}$ & 3 & 0,08 & 0,24 \\
\hline & Produksi keripik singkong lebih cepat dan praktis & 3 & 0,07 & 0,21 \\
\hline & Olahan pangan dari rambut jagung merupakan inovasi produk & 3 & 0,07 & 0,21 \\
\hline & Trend konsumsi pangan yang menyehatkan dari olahan hasil pertanian & 3 & 0,09 & 0,27 \\
\hline & Berkembangnya kemampuan masyarakat akan pemasaran online & 2 & 0,12 & 0,24 \\
\hline \multirow[t]{2}{*}{ Pendidikan } & $\begin{array}{l}\text { Membangun dan mendorong majunya bidang pendidikan baik formal } \\
\text { maupun informal yang mudah diakses dan dinikmati seluruh warga } \\
\text { masyarakat }\end{array}$ & 2 & 0,07 & 0,14 \\
\hline & $\begin{array}{l}\text { Wajib belajar anak didik } 9 \text { tahun, dengan target lima tahun kedepan } \\
\text { sudah tidak ada lagi masyarakat yang buta huruf }\end{array}$ & 3 & 0,08 & 0,24 \\
\hline \multirow{3}{*}{$\begin{array}{l}\text { Administrasi } \\
\text { desa }\end{array}$} & $\begin{array}{l}\text { Meningkatnya profesionalisme kerja } \\
\text { perangkat desa }\end{array}$ & 2 & 0,08 & 0,16 \\
\hline & $\begin{array}{l}\text { Terbukanya tertib administrasi pendokumentasian data kegiaatan } \\
\text { pemerintahan desa }\end{array}$ & 3 & 0,07 & 0,21 \\
\hline & Jumlah & & 1,45 & 3,89 \\
\hline
\end{tabular}

Sumber: Hasil analisis data (2019).

Tabel 4 Identifikasi faktor ancaman Desa Panggungduwet dari rencana pengembangan program KKN Bela Negara Desa Prioritas Nasional

\begin{tabular}{|c|c|c|c|c|}
\hline Bidang & Uraian & Skor & Bobot & Nilai \\
\hline \multirow[b]{2}{*}{ Lingkungan } & Penebangan pohon yang dilakukan untuk kepentingan pribadi & 4 & 0,08 & 0,32 \\
\hline & $\begin{array}{l}\text { Pupuk anorganik masih banyak digunakan } \\
\text { oleh petani }\end{array}$ & 4 & 0,07 & 0,28 \\
\hline \multirow{3}{*}{$\begin{array}{l}\text { Pengolahan } \\
\text { limbah }\end{array}$} & Pengeluaran biaya perawatan untuk alat pemotong tinggi & 4 & 0,06 & 0,24 \\
\hline & Souvenir serupa dengan kualitas lebih bagus & 3 & 0,07 & 0,21 \\
\hline & $\begin{array}{l}\text { Sifat pemalas petani untuk pembuatan pupuk organik secara } \\
\text { berkala }\end{array}$ & 4 & 0,15 & 0,60 \\
\hline \multirow{3}{*}{$\begin{array}{l}\text { Olahan } \\
\text { pangan }\end{array}$} & $\begin{array}{l}\text { Kurang kompaknya antar warga, sehingga sering menimbulkan } \\
\text { gesekan dan konflik kepentingan }\end{array}$ & 4 & 0,08 & 0,32 \\
\hline & Sirup rambut jagung mudah dibuat sehingga mudah untuk ditiru & 3 & 0,07 & 0,21 \\
\hline & $\begin{array}{l}\text { Keripik singkong sudah banyak pesaing } \\
\text { produk serupa }\end{array}$ & 3 & 0,08 & 0,24 \\
\hline \multirow[t]{2}{*}{ Pendidikan } & $\begin{array}{l}\text { Minat anak-anak di desa Panggung Duwet menurun setelah } \\
\text { kepulangan peserta KKN }\end{array}$ & 4 & 0,07 & 0,28 \\
\hline & Tidak ada masyarakat yang melanjutkan kegiatan pengajaran & 4 & 0,15 & 0,60 \\
\hline \multirow{2}{*}{$\begin{array}{l}\text { Administrasi } \\
\text { desa }\end{array}$} & $\begin{array}{l}\text { Administrasi di desa Panggung Duwet kembali awal (kacau) setelah } \\
\text { kepulangan peserta KKN }\end{array}$ & 4 & 0,12 & 0,48 \\
\hline & $\begin{array}{l}\text { Perangkat desa enggan kembali mengoperasionalkan komputer } \\
\text { untuk pelayanaan masyarakat }\end{array}$ & 4 & 0,12 & 0,48 \\
\hline Jumlah & & & 1,12 & 4,26 \\
\hline
\end{tabular}

Sumber: Hasil analisis data (2019). 
Berdasar tabel analisis lingkungan internal dan eksternal Desa Panggungduwet yang telah dikemukakn, dapat diketahui bahwa bobot masing-masing variabel adalah $\mathrm{S}=3,80 ; \mathrm{W}=$ 4,08; $0=3,89$ dan $T=4,26$. Variabel-variabel tersebut dimasukkan kedalam diagram SWOT dan dari sumbu Y yaitu $S-W=-0,3$ dan sumbu $X$ yang dibentuk dari $0-\mathrm{T}=-0,4$, seperti terlihat pada Gambar 7. Gambar 7 memperlihatkan posisi potensi Desa Panggungduwet, Kecamatan Kademangan, Kabupaten Blitar menuju desa maju dan mandiri berdasar perspektif KKN Bela Negara Desa Prioritas Nasional berada di Kuadran 3, artinya fokus strategi ini adalah meminimalkan masalah-masalah internal sehingga dapat merebut peluang pengelolaan potensi desa yang lebih baik.

\section{SIMPULAN}

Pelaksanaan KKN Bela Negara Desa Prioritas Nasional banyak memahami berbagai persoalanpersoalan yang terjadi di masyarakat Desa Panggung Duwet, Kecamatan Kademangan, Kabupaten Blitar dan berpartisipasi melakukan intervensi sosial melalui progam kerja seperti penghijauan, pengolahan limbah menjadi pupuk organik dan kerajinan, pengolahan komoditas utama menjadi produk unggulan seperti sirup rambut jagung, donat singkong dan keripik singkong.

Analisis situasi desa digambarkan pada posisi Kuadran 3, artinya fokus strategi ini adalah meminimalkan masalah-masalah internal sehingga dapat merebut peluang yang lebih baik, atau dalam kata lain posisi desa masih terdapat kelemahan yaitu kurangnya kesediaan air, terutama di musim kemarau untuk pertanian akan diselesaikan dengan peluang yang ada di

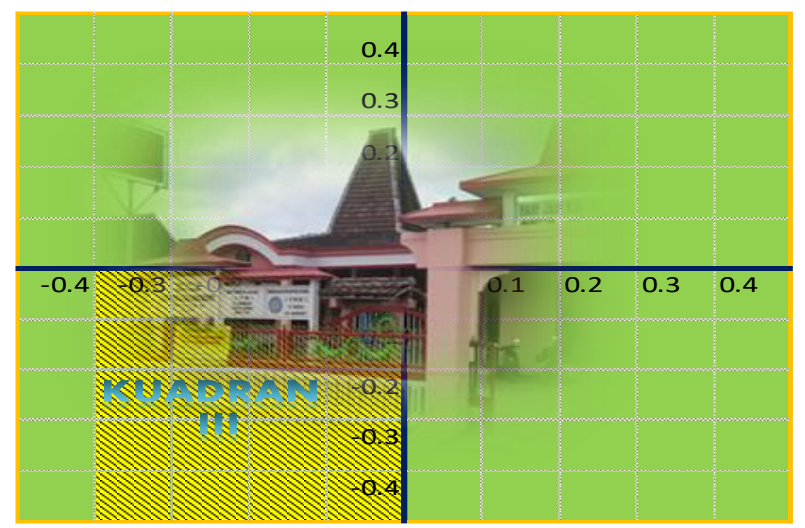

Gambar 7 Diagram SWOT potensi Desa Panggung Duwet menuju desa maju dan mandiri. antaranya mengupayakan pupuk organik dengan memanfaatkan limbah dan kerajinan limbah gergaji kayu dijual dalam bentuk souvenir pernikahan sehingga potensi tersebut diharapkan menjadi katalisator perkembangan desa menjadi maju dan mandiri. Menyadari sepenuhnya bahwa tidak mudah merubah kebiasaan masyarakat untuk merealisasikan pemikiran konservasi tanah dan air guna pengurangan degradasi lahan hanya dalam kurun waktu singkat. Akan tetapi, kehadiran KKN dapat meninggalkan kesan yang baik sehingga masyarakat mulai merubah perilaku buruk pengelolaan lahan pertanian yang mengabaikan kaidah konservasi dan bertambahnya pengetahuan dan ketrampilan olahan limbah maupun olahan pangan yang bernilai ekonomis tinggi.

\section{UCAPAN TERIMA KASIH}

Tim Abdimas KKN Bela Negara Prioritas Nasional mengungkapkan terima kasih sebesarbesarnya kepada LPPM UPN "Veteran" Jawa Timur yang berkontribusi penuh perihal pendanaan selama kegiatan berlangsung beserta luaran jurnal yang disusun untuk dipublikasikan.

\section{DAFTAR PUSTAKA}

Adi IR. 2005. Ilmu Kesejahteraan Sosial dan Pekerjaan Sosial: Pengantar Pada Pengertian dan Beberapa Pokok Bahasan. Jakarta (ID): UI Press.

Dariah A, Rahman A, Kurnia U. 2004. Erosi dan Degradasi Lahan Kering di Indonesia. Dalam: Kurnia U, Rachman A, Dariah A. (editor). Teknologi Konservasi Tanah Pada Lahan Berlereng. Pusat Penelitian dan Pengembangan Tanah dan Agroklimat. Bogor (ID). Hal. 1-6.

Doust SJ, Erskine PD, Lamb D. 2008. Restoring rainforest species by direct seeding: Tree Seedling Establishment and Growth Performance on Degraded Land in The Wet Tropics of Australia. Forest Ecology and Management. $256 \quad$ (5): 1178-1188. https://doi.org/10.1016/j.foreco.2008.06.01 9

Gray LC, Moseley WG. 2005. A geographical perspective on poverty-environment interactions. The Geographical Journal. 
171(1): 9-23. https://doi.org/10.1111/ j.1475-4959.2005.00146.x

Jendoubia D, Hossain MS, Gigera M, Dublj evićc JT, Ouessard M, Liginer H, Speranza CI, 2020. Local Livelihoods and Land Users' Perceptions of Land Degradation in Northwest Tunisia. Environmental Development. 33: 1-17. https://doi.org/10.1016/j.envdev.2020.1005 07

Kementerian Pembangunan Desa, Pembangunan Daerah Tertinggal, dan Transmigrasi (2015). Indeks Desa Membangun. Jakarta (ID): Kemendes PDTT.

Kertez A. 2009. The Global Problem of Land Degradation and Desertification. Hungarian Geographical Bulletin. 58 (1): 19-31.

Prăvălie R, Săvulescu I, Patriche C, Dumitraşcu M, Bandoc G. 2017. Spatial assessment of land degradation sensitive areas in southwestern Romania using modified MEDALUS method. Catena. 153: 114-130. https://doi.org/ 10.1016/j.catena.2017.02.011

Rahadi B, Suharto B, Nugraha MI. 2016. Evaluasi Penggunaan Lahan Rencana Tata Ruang
Wilayah Kabupaten Blitar Tahun 2011-2031 Berdasarkan Kelas Kemampuan Lahan. Jurnal Sumberdaya Alam dan Lingkungan. 3(3): 2635.

Rangkuti F. 2014. Analisis SWOT: Teknik Membedah Kasus Bisnis. Jakarta (ID): PT Gramedia Pustaka Utama.

Sadesmesli I, Baskoro DPT, Pravitasari AE. 2017. Daya Dukung Lahan Dalam Perencanaan Tata Ruang Wilayah (Studi Kasus Kabupaten Blitar, Jawa Timur). Tata Loka. 19(4): 266-279.

Sitorus SRP. 2004. Evaluasi Sumber Daya Lahan. Bandung (ID): PT Tarsito.

Suharto E. 2007. Pekerjaan Sosial Di Dunia Industri; Memperkuat Tanggung jawab Sosial Perusahaan (Corporate Social Responsibility). Bandung (ID): Refika Aditama.

Wang Y, Li Y. 2019. Promotion of Degraded Land Consolidation to Rural Poverty Alleviation in The Agro-Pastoral Transition Zone of Northern China. Land Use Policy. 88: 104-114. https://doi.org/10.1016/j.landusepol.2019.1 04114 